OPEN ACCESS

Edited by:

Fernando Gomollón University of Zaragoza, Spain

Reviewed by:

Hakan Akin,

Marmara University, Turkey Alejandro Piscoya,

Saint Ignatius of Loyola

University, Peru

*Correspondence:

Qiang Xiao

xq_doc@163.com

Specialty section: This article was submitted to Gastroenterology,

a section of the journal

Frontiers in Medicine

Received: 30 December 2020 Accepted: 12 March 2021 Published: 07 April 2021

Citation:

Zhao C, Wang J and Xiao Q (2021) Efficacy of Teprenone for Prevention of NSAID-Induced Gastrointestinal Injury: A Systematic Review and Meta-Analysis. Front. Med. 8:647494. doi: 10.3389/fmed.2021.647494

\section{Efficacy of Teprenone for Prevention of NSAID-Induced Gastrointestinal Injury: A Systematic Review and Meta-Analysis}

\author{
Chongxiang Zhao, Jingwu Wang and Qiang Xiao* \\ Department of Gastroenterology, Zaozhuang Hospital of Traditional Chinese Medicine, Zaozhuang, China
}

Background: The study aimed to conduct a systematic review and meta-analysis comparing the efficacy of teprenone with control or other drugs for reducing the incidence of gastrointestinal (GI) adverse events in patients receiving long-term non-steroidal anti-inflammatory drugs (NSAIDs).

Methods: Databases of PubMed, Embase, BioMed Central, CENTRAL, and Google Scholar were searched up to November 10th, 2020 for randomized controlled trials (RCTs) comparing teprenone with control or other drugs. A random-effects model was used for the meta-analysis. Grading of Recommendations Assessment, Development, and Evaluation (GRADE) tool was used for assessing the certainty of evidence.

Results: Seven RCTs were included. Six compared teprenone with control and one with famotidine. Meta-analysis indicated a statistically significant reduced risk of Gl ulcers in patients receiving teprenone as compared to control after 12 weeks/3months (RR $0.3795 \% \mathrm{Cl} 0.17,0.18 l^{2}=0 \% p=0.01$ ). Pooled data of three open-label studies indicated statistically significant reduction of $\mathrm{Gl}$ symptoms in patients on teprenone as compared to control at 6 months and 12 months, but not at 3 months. Comparing teprenone with control, our analysis indicated non-significant but a tendency of better reduction in Modified Lanza Score (MLS) with teprenone. The RCT comparing teprenone to famotidine demonstrated better reduction of MLS with famotidine. The certainty of evidence-based on GRADE was deemed to be low.

Conclusion: Low-quality evidence indicates a beneficial role of teprenone in preventing Gl injuries in patients receiving long-term NSAIDs. Further high-quality RCTs comparing teprenone with placebo as well as other gastroprotective drugs are needed to strengthen current evidence.

Keywords: teprenone, aspirin, NSAID, complication, ulcer, gastrointestinal

\section{INTRODUCTION}

Non-steroidal anti-inflammatory drugs (NSAIDs) are commonly prescribed in patients with cardiovascular, cerebrovascular, and rheumatoid disease $(1,2)$. Long-term treatment is usually required in such patients either for therapeutic purposes or for the prevention of adverse cardiovascular events like myocardial infarction and stroke. Among these drugs, low-dose aspirin 
has been the most commonly prescribed medication which has been in clinical use for several decades (1). It is known that even low doses of NSAIDs can result in gastrointestinal (GI) adverse events ranging from dyspeptic symptoms to ulcers and severe bleeding (3). However, the withdrawal of long-term NSAIDs can lead to increased mortality and other cardiovascular adverse events (4). Thus, a fine balance is to be maintained in clinical practice so that the benefits of long-term NSAIDs do not outweigh the associated risks.

The primary mechanism by which NSAIDs cause adverse GI events is by depletion of prostaglandin secretion and by direct topical injury (5). Since gastric acid is closely related to the pathogenesis of such adverse events, concurrent administration of acid-suppressing drugs like proton pump inhibitors (PPIs) and H2-receptor antagonists (H2RAs) is the commonly recommended strategy to prevent NSAID-induced GI side-effects (6). The efficacy of PPIs in reducing the incidence of GI adverse events is well-established in the literature (7). However, there have been concerns of increased risk of fractures, infections, and possible risk of dementia and renal disease with long-term use of PPIs (8). Furthermore, PPIs are expensive and may also affect platelet response thus reducing the efficacy of low-dose aspirin $(9,10)$. A recent narrative review on the use of PPIs for long-term treatment of gastroesophageal reflux has reiterated the efficacy of PPIs but has also highlighted the high-cost associated with long term treatment (10). Thus, an effective and safe alternative drug would enhance the spectrum of medications available to physicians for long-term prophylaxis against gastric injury.

Teprenone or geranylgeranylacetone is an anti-ulcerative drug that has been used for treating gastritis and gastric ulcers in several Asian countries. The drug is an acyclic isoprenoid compound that acts by activating heat shock protein 70 (HSP70). HSP70 is a cellular protective protein that prevents mucosal injury caused by agents like NSAIDs without affecting gastric acid secretion (11). Animal studies have demonstrated that teprenone can prevent NSAID-induced gastric as well as small intestinal injuries $(12,13)$. The efficacy of the drug has also been tested in several human trials, however, to the best of our knowledge there has been no effort to analyze and pool available evidence to guide clinical practice. Thus, the current study aimed to conduct a systematic literature search for studies comparing the efficacy of teprenone with control or other gastroprotective drugs for reducing the incidence of GI adverse events in patients receiving long-term NSAIDs and pool data for a meta-analysis.

\section{MATERIALS AND METHODS}

\section{Search Strategy}

The review was conducted following the PRISMA statement (Preferred Reporting Items for Systematic Reviews and Metaanalyses) (14) and the Cochrane Handbook for Systematic Reviews of Intervention (15). Articles on the subject of the review were searched in the electronic databases of PubMed, Embase, BioMed Central, CENTRAL, and Google Scholar up to November 10th, 2020. Databases were searched from inception and without any language restriction. We used the following keywords in different combinations for the literature search: "teprenone," "geranylgeranylacetone," "gastrointestinal," "gastric," "small intestine," "injury," and "ulcer." Supplementary Table 1 depicts the search strategy of the review. Two reviewers carried out the electronic search independent of each other. The primary search results were assessed initially by their titles and abstracts to identify citations requiring full-text analysis. The full-texts of the articles were reviewed by the two reviewers independently based on the inclusion and exclusion criteria. Any disagreements were resolved by discussion. Furthermore, we also hand-searched the bibliography of included studies for any missed references.

\section{Inclusion Criteria}

To maintain clarity on the inclusion criteria, the PICOS (Population, Intervention, Comparison, Outcome, and Study design) guide was used to include studies. The following criteria were used for each domain:

Population: Adult patients prescribed long-term (at least 12 weeks or 3 months) NSAID therapy for any disease.

Intervention: Teprenone for the duration of NSAID therapy.

Comparison: Placebo or any other comparative drug (PPI or H2RA).

Outcomes: Incidence of GI ulcers or GI symptoms.

Study design: Randomized controlled trials (RCTs).

Studies were included irrespective of sample size and the dosage of drugs. Studies not using teprenone as a preventive drug for GI ulcers, studies using combinations of more than one NSAID, and studies using a combination of teprenone with other GI protective agents like PPI/H2RA in the intervention group were excluded. We also excluded non-RCTs, retrospective studies, animal studies, and review articles.

\section{Data Extraction}

A data extraction sheet was prepared for extracting data from the included studies. Two reviewers extracted data independently. Data regarding the first author, publication year, study location, patient population, sample size, demographic details, study and control drug protocol, Helicobacter pylori status, study outcomes, and follow-up period were extracted. The outcomes of interest of our review were the incidence of GI ulcers detected on follow-up endoscopy, the incidence of GI symptoms, and the Modified Lanza Score (MLS) if available. Outcome data was fed into meta-analysis software and cross-checked for correctness. We attempted to contact the corresponding author via email in case of any missing data. Any other outcomes reported by the included studies were presented in a tabular format.

\section{Risk of Bias Assessment}

The risk of bias was assessed using the Cochrane Collaboration's risk of bias assessment tool-2 by two reviewers independently (15). The following seven domains were used for quality assessment: random sequence generation, allocation concealment, blinding of participants and personnel, blinding of outcome assessment, incomplete outcome data, selective reporting, and other bias. Any disagreements were resolved by 


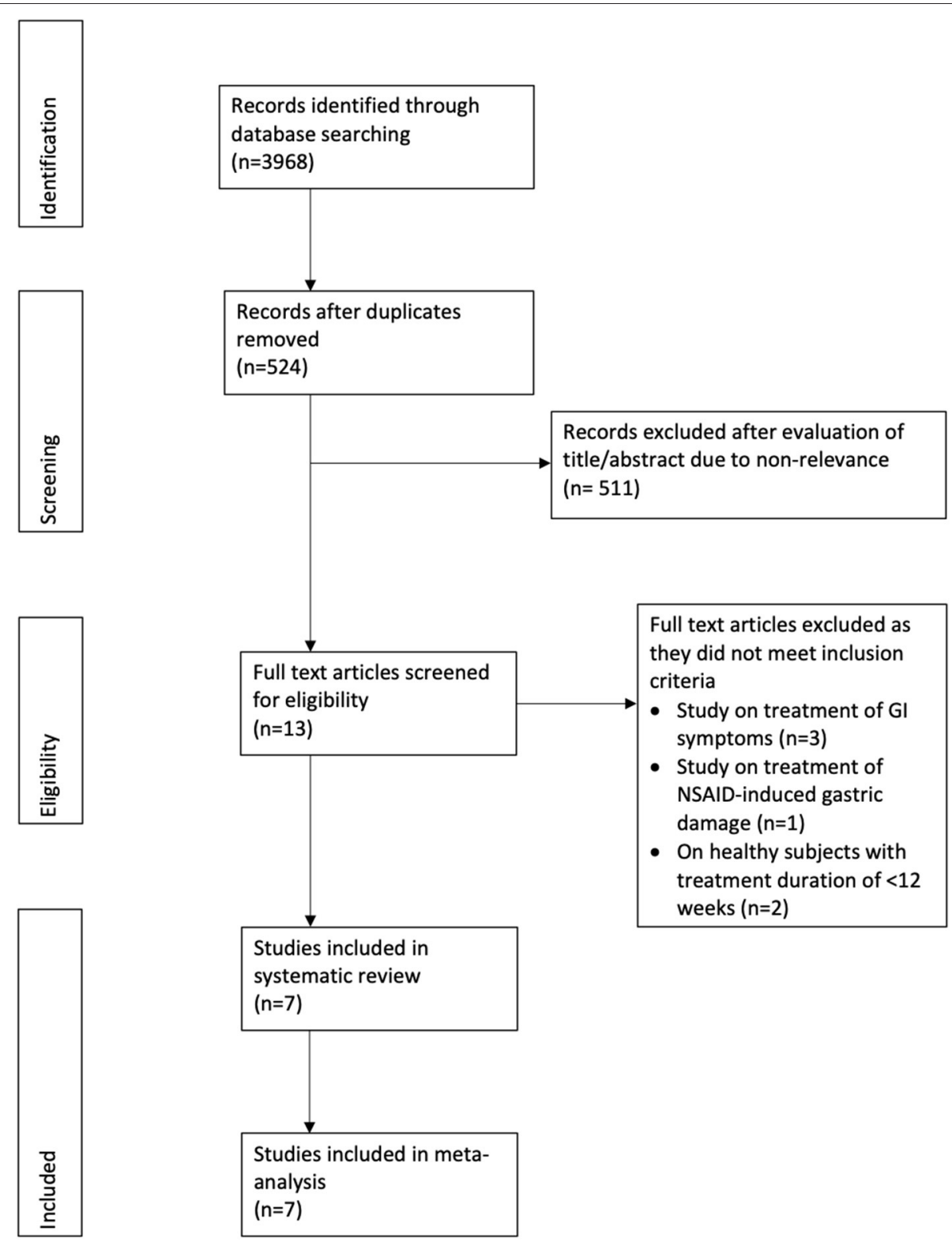

FIGURE 1 | Study flow-chart.

discussion. The certainty of the evidence was assessed by the Grading of Recommendations Assessment, Development, and Evaluation (GRADE) tool. The GRADEpro GDT software was used for this purpose [GRADEpro Guideline Development Tool. McMaster University, 2020 (developed by Evidence Prime, Inc.)].

\section{Statistical Analysis}

The software "Review Manager" [RevMan, version 5.3; Nordic Cochrane Center (Cochrane Collaboration), Copenhagen, Denmark; 2014] was used for the meta-analysis. Incidence of GI ulcers and symptoms were summarized using Risk Ratios (RR) with 95\% confidence intervals (CI). MLS were pooled using Mean Difference (MD) with 95\% CI. Sub-group analyses were carried out for comparing teprenone with control and other drugs. The random-effects model was used for all the meta-analyses. Heterogeneity was assessed using the $I^{2}$ statistic. $I^{2}$-values of $25-50 \%$ represented low, values of 50-75\% medium, and more than $75 \%$ represented substantial heterogeneity. Due to the inclusion of fewer than 10 studies in the review, funnel plots were not used to assess publication bias.

\section{RESULTS}

The study flow chart is presented in Figure 1. A total of seven RCTs (16-22) were included in the review (Table 1). Most trials were conducted in China, with one each in Japan (21) and Thailand (18). All trials had excluded patients with GI ulcers and bleeding at baseline. Aspirin was the NSAID used in five 
TABLE 1 | Details of included studies.

\begin{tabular}{|c|c|c|c|c|c|c|c|c|c|c|c|}
\hline References & $\begin{array}{l}\text { Study } \\
\text { location }\end{array}$ & Study population & $\begin{array}{l}\text { Teprenone } \\
\text { dosage }\end{array}$ & Control drug & Sample size & Mean age (years) & $\begin{array}{l}\text { Male gender } \\
(\%)\end{array}$ & $\begin{array}{l}\text { Smokers } \\
(\%)\end{array}$ & $\begin{array}{l}\text { Helicobacter } \\
\text { pylori status }\end{array}$ & $\begin{array}{l}\text { Definition of } \\
\text { gastrointestinal } \\
\text { ulcer }\end{array}$ & Follow-up \\
\hline \multirow[t]{2}{*}{$\begin{array}{l}\text { Chitapanarux } \\
\text { et al. (18) }\end{array}$} & Thailand & $\begin{array}{l}\text { Aspirin-naïve patients } \\
\text { needing low-dose aspirin } \\
\text { for cardiovascular or } \\
\text { cerebrovascular disease }\end{array}$ & $\begin{array}{l}50 \mathrm{mg} \text { thrice } \\
\text { daily }\end{array}$ & Placebo & Teprenone: 64 & $59.62 \pm 6.35$ & 53.1 & 12.5 & Negative & $\begin{array}{l}\text { Defect more than } \\
\text { submucosal layer } \\
\text { at least } 3 \mathrm{~mm} \text { in } \\
\text { diameter in the } \\
\text { stomach or } \\
\text { duodenum }\end{array}$ & 12 weeks \\
\hline & & & & & Control: 66 & $58.73 \pm 5.48$ & 54.5 & 18.2 & Negative & & \\
\hline \multirow[t]{2}{*}{ Zhao et al. (19) } & China & $\begin{array}{l}\text { Aspirin-naïve patients } \\
\text { needing low-dose aspirin } \\
\text { for cardiovascular or } \\
\text { cerebrovascular disease }\end{array}$ & $\begin{array}{l}50 \mathrm{mg} \text { thrice } \\
\text { daily }\end{array}$ & No drug & Teprenone: 131 & $65.73 \pm 10.30$ & 50.4 & 19.1 & NR & Not defined & $\begin{array}{l}3,6,12 \\
\text { months }\end{array}$ \\
\hline & & & & & Control: 136 & $67.24 \pm 9.21$ & 53.7 & 21.3 & NR & & \\
\hline \multirow[t]{2}{*}{ Gong et al. (20) } & China & $\begin{array}{l}\text { Rheumatic, } \\
\text { cardiovascular, } \\
\text { cerebrovascular disease } \\
\text { patients on long term } \\
\text { NSAID or low-dose aspirin }\end{array}$ & $\begin{array}{l}50 \mathrm{mg} \text { thrice } \\
\text { daily }\end{array}$ & No drug & Teprenone: 74 & $54 \pm 20$ & 50 & 16 & Negative & Not defined & 12 weeks \\
\hline & & & & & Control: 84 & $55 \pm 18$ & 47.6 & 13.1 & Negative & & \\
\hline \multirow[t]{2}{*}{$\begin{array}{l}\text { Takeuchi et al. } \\
\text { (21) }\end{array}$} & Japan & $\begin{array}{l}\text { Patients requiring } \\
\text { low-dose aspirin for } \\
\text { cardiovascular, } \\
\text { cerebrovascular, or any } \\
\text { disease }\end{array}$ & $\begin{array}{l}50 \mathrm{mg} \text { thrice } \\
\text { daily }\end{array}$ & $\begin{array}{l}\text { Famotidine } \\
20 \text { mg daily }\end{array}$ & Teprenone: 28 & $66.5 \pm N R$ & 64.2 & 25 & Positive: $39.2 \%$ & Not defined & 12 weeks \\
\hline & & & & & Control: 38 & $72.5 \pm N R$ & 57.8 & 7.8 & Positive: $14 \%$ & & \\
\hline \multirow[t]{2}{*}{ Xiong et al. (22) } & China & $\begin{array}{l}\text { Rheumatic disease } \\
\text { patients not on NSAIDs } \\
\text { for at least } 6 \text { months } \\
\text { needing diclofenac }\end{array}$ & $\begin{array}{l}50 \mathrm{mg} \text { thrice } \\
\text { daily }\end{array}$ & No drug & Teprenone: 21 & $31 \pm 9$ & 42.9 & 4.8 & NR & $\begin{array}{l}\text { Mucosal breaks } \\
\text { with white or } \\
\text { yellow bases sur- } \\
\text { rounded by red or } \\
\text { pink collars }\end{array}$ & 12 weeks \\
\hline & & & & & Control: 19 & $31 \pm 11$ & 68.4 & 21.1 & NR & & \\
\hline \multirow[t]{2}{*}{ Lu (16) } & China & $\begin{array}{l}\text { Patients requiring } \\
\text { low-dose aspirin for } \\
\text { cardiovascular, } \\
\text { cerebrovascular, or any } \\
\text { disease }\end{array}$ & $\begin{array}{l}50 \mathrm{mg} \text { thrice } \\
\text { daily }\end{array}$ & No drug & Teprenone: 42 & $N R$ & $N R$ & NR & NR & Not studied & $\begin{array}{l}3,6,12 \\
\text { months }\end{array}$ \\
\hline & & & & & Control: 42 & NR & NR & NR & NR & & \\
\hline \multirow[t]{2}{*}{ Wu et al. (17) } & China & $\begin{array}{l}\text { Aspirin-naïve patients } \\
\text { needing low-dose aspirin } \\
\text { for cardiovascular or } \\
\text { cerebrovascular disease }\end{array}$ & $\begin{array}{l}50 \mathrm{mg} \text { thrice } \\
\text { daily }\end{array}$ & No drug & Teprenone: 118 & $69.5 \pm 10.4$ & NR & NR & NR & Not defined & $\begin{array}{l}3,6,12 \\
\text { months }\end{array}$ \\
\hline & & & & & Control: 143 & $69 \pm 9.3$ & NR & NR & NR & & \\
\hline
\end{tabular}

NSAID, Non-steroidal anti-inflammatory drug; NR, not reported. 


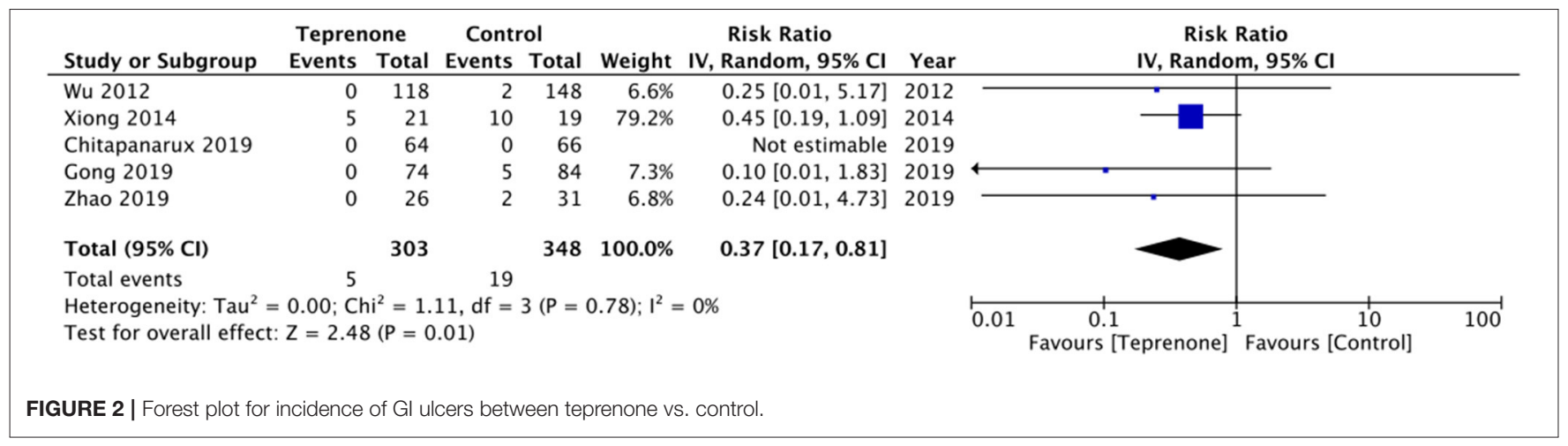

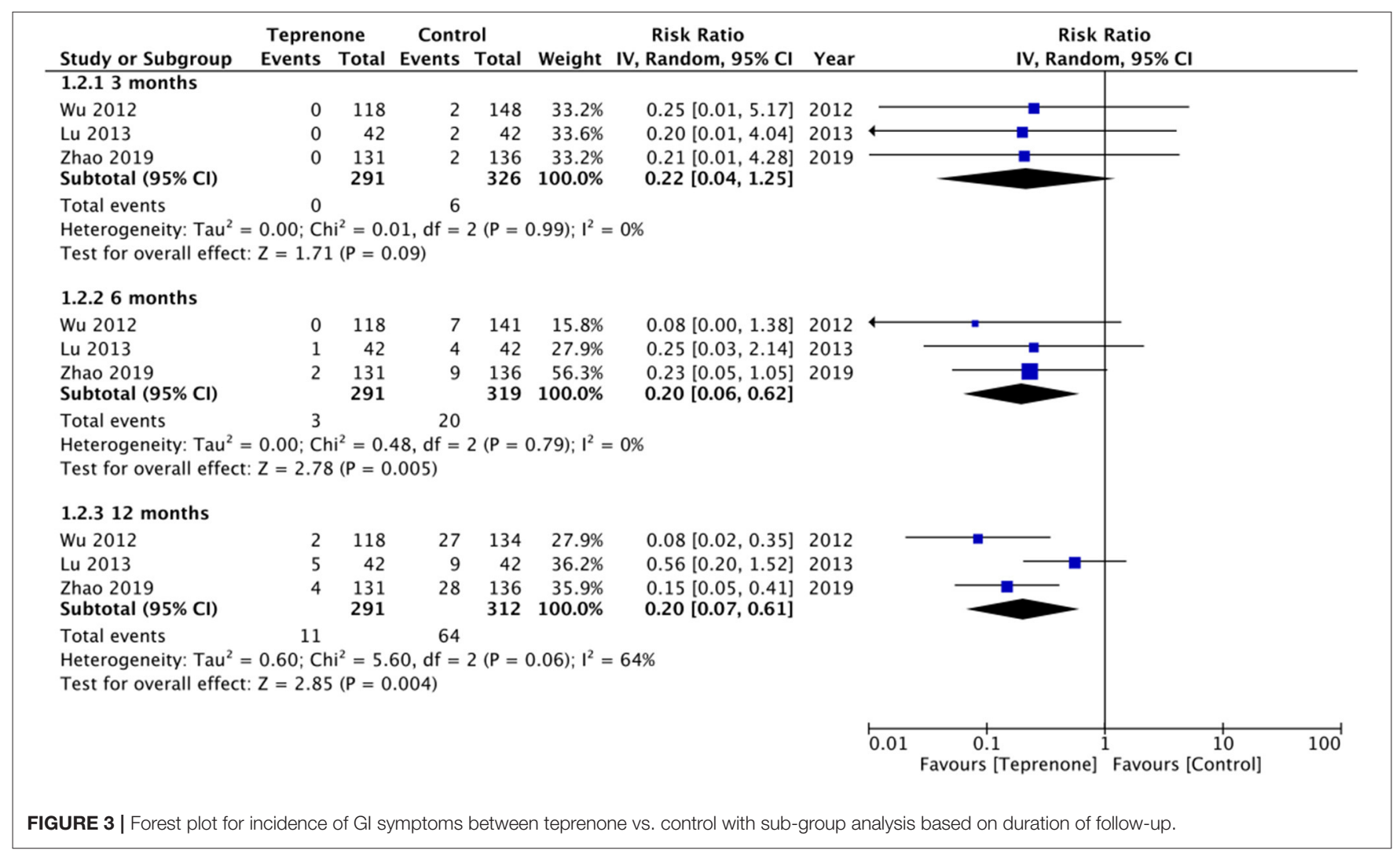

trials, one trial (22) used diclofenac while the remaining study (20) used either NSAID or aspirin. The same dosage of teprenone was used in all studies (50 mg thrice daily for a total dose of 150 $\mathrm{mg} /$ day). Only one trial (22) compared teprenone with another drug (Famotidine). Helicobacter pylori status was not reported in four studies $(16,17,19,22)$. The follow-up ranged from a minimum of 12 weeks/ 3 months to 12 months.

\section{Meta-Analysis}

Of the six trials comparing teprenone with control, four reported incidence of gastric ulcers while one study reported the incidence of small-intestinal ulcers. Meta-analysis indicated a statistically significant reduced risk of GI ulcers in patients receiving teprenone as compared to control after 12 weeks/3 months (RR $0.3795 \%$ CI $0.17,0.18 I^{2}=0 \% p=0.01$ ) (Figure 2). The lone trial of Takeuchi et al. (21) comparing teprenone with famotidine reported zero incidences of GI ulcers in both study groups after a follow-up of 12 weeks. The incidence of subjective GI symptoms was pooled from three studies. Our meta-analysis demonstrated no statistically significant difference in the incidence of GI symptoms between the two groups at 3 months (RR 0.22 95\% CI $\left.0.01,1.25 I^{2}=0 \% p=0.09\right)$ but a significant reduction in GI symptoms at 6 months (RR $0.2095 \%$ CI 0.06, $0.62 I^{2}=0 \%$ $p=0.005)$ and 12 months (RR $0.2095 \%$ CI $0.07,0.61 I^{2}=$ $64 \% p=0.004)$ in patients on teprenone as compared to control (Figure 3). MLS were reported by just three studies. Pooling data from two studies comparing teprenone with control, our analysis indicated a tendency of non-significant but better reduction in MLS with teprenone (MD - $1.0995 \%$ CI $-2.27,0.09 I^{2}=$ $98 \% p=0.07$ ) (Figure 4). On analysis of data from the study 


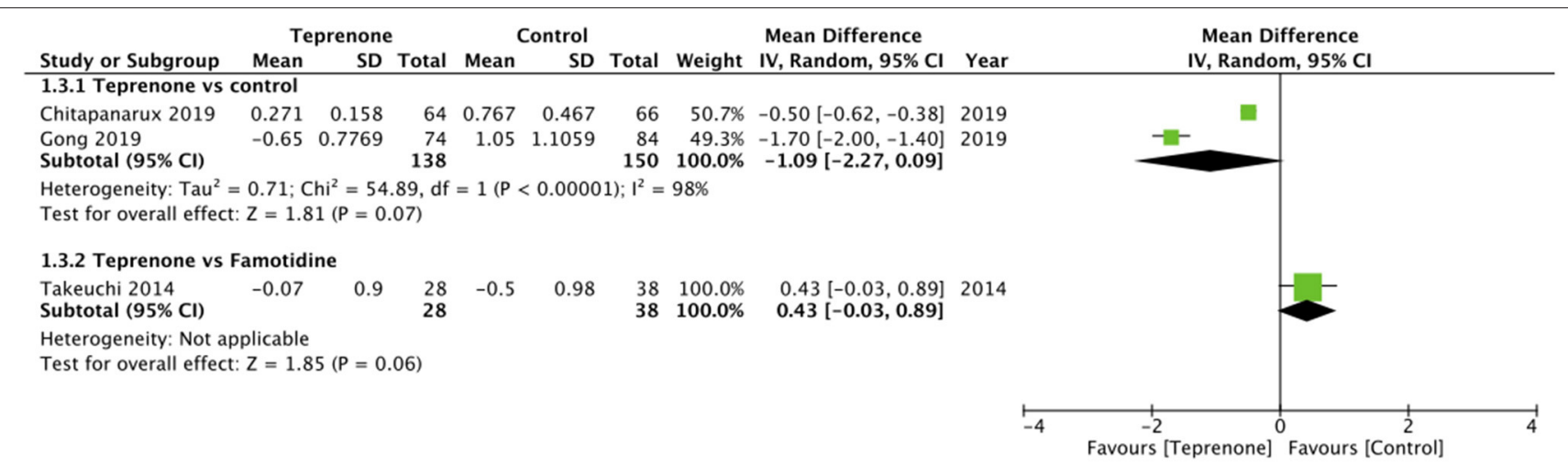

FIGURE 4 | Forest plot for MLS with sub-group analysis based on comparative group.

of Takeuchi et al. (21) comparing teprenone with famotidine, the results indicated a tendency of non-significant but better reduction of MLS with famotidine (MD $0.4395 \% \mathrm{CI}-0.03,0.89$ $p=0.06$ ) (Figure 4). The certainty of evidence based on GRADE was deemed to be low for all outcomes (Supplementary Table 2).

\section{Other Outcomes}

Details of all outcomes reported by the included studies along with their results are presented in Table 2. No case of GI bleeding was reported in either the study or control group by four studies (18-21). Xiong et al. (22) used the Lewis score to assess smallintestinal injuries and reported significantly higher scores in the control group.

No major or serious adverse events were reported in either group by any trial. None of the studies reported any treatmentrelated discontinuation of any drugs. Only Chitapanarux et al. (18) reported details of specific adverse events. The side-effects reported were nausea (teprenone: 6.25\% vs. placebo: 9.09\%) and heartburn (teprenone: $9.37 \%$ vs. placebo: 9.09\%).

\section{Risk of Bias}

The risk of bias summary is presented in Figure 5. The majority of the studies did not report adequate information on allocation concealment. Only one trial reported blinding of participants and personnel (18). There was a high risk of bias in blinding of outcome assessment in three studies $(16,17,19)$. Attrition bias was high in the study of Zhao et al. (19).

\section{DISCUSSION}

The results of the first systematic review and meta-analysis assessing the preventive efficacy of teprenone against NSAIDinduced GI injury presents the following important findings: (1) As compared to placebo or no drug, teprenone significantly reduces the incidence of GI ulcers by $63 \%$ at 12 weeks $/ 3$ months and reduces the incidence of GI symptoms at 6 months/1 year. (2) On endoscopic evaluation, the degree of GI injury measured by MLS shows a tendency of better reduction by teprenone. (3) The lone RCT comparing teprenone with famotidine, however, demonstrated a tendency of better outcomes with the H2RA. Important to note is the limited number of studies in the meta-analysis and low certainty of evidence on GRADE for all outcomes.

Of available NSAIDs, low-dose aspirin is a valuable antithrombotic medication used in several cardiovascular and cerebrovascular diseases. However, the GI adverse effects of even a low dose of the drug are of clinical concern. A number of studies conducted in different geographical regions worldwide have reported the prevalence of endoscopic GI ulcers as well as erosions with low-dose aspirin (23). In one of the largest studies, Uemura et al. (24) detected gastroduodenal ulcers and erosion in 6.5 and $29.2 \%$ of Japanese patients on long-term lowdose aspirin. In another multi-centric study, Yeomans et al. (25) reported the prevalence of gastric ulcers to be $10.7 \%$ in patients on low-dose aspirin. The prevalence of GI ulcers has varied in different geographical regions with studies reporting prevalence to be as high as $43 \%$ in patients receiving long-term NSAIDs, with diclofenac and aspirin being the most common NSAIDs associated with such adverse event (26). Thus, it is important for clinicians using NSAIDs to be aware of such GI injuries and take preventive measures by prescribing gastroprotective medications (27).

In this context, our review is important as it presents level-1 evidence on one such drug i.e., teprenone by pooling evidence from only RCTs. Endoscopic assessment of patients in the study and control groups at 12 weeks/ 3 months revealed the incidence of GI ulcers to be 1.6 and $5.4 \%$, respectively. On pooling this data for a meta-analysis, our results indicated that teprenone is effective in reducing the incidence of GI ulcers when prescribed with long-term NSAIDs as compared to patients not receiving any drug or placebo. The preventive efficacy of teprenone can be attributed to its unique mechanism of action. It is wellknown that inhibition of prostaglandin synthesis is an important component of NSAID-induced gastric injury. Teprenone not only promotes the endogenous synthesis of prostaglandins but also aids in the repair of mucosal integrity by limiting mucosal erosions and increasing mucous secretion without affecting gastric acid secretion $(28,29)$. This is especially important in the context of small intestinal injuries where the role of gastric acid is limited and decreased mucus secretion and increased mucosal permeability are important factors causing intestinal lesions (30). The trial of Xiong et al. (22) was the lone RCT in 
TABLE 2 | Details of outcomes and results reported by the included studies.

\begin{tabular}{|c|c|c|}
\hline References & Outcome & Result \\
\hline \multirow[t]{8}{*}{$\begin{array}{l}\text { Chitapanarux } \\
\text { et al. (18) }\end{array}$} & Incidence of gastric ulcer & $\begin{array}{l}\text { No significant difference between } \\
\text { the two groups }\end{array}$ \\
\hline & Incidence of Gl bleeding & $\begin{array}{l}\text { No significant difference between } \\
\text { the two groups }\end{array}$ \\
\hline & $\begin{array}{l}\text { Incidence of gastric } \\
\text { erosion }\end{array}$ & $\begin{array}{l}\text { Significantly higher in the } \\
\text { placebo group }\end{array}$ \\
\hline & Incidence of gastritis & $\begin{array}{l}\text { Significantly higher in the } \\
\text { placebo group }\end{array}$ \\
\hline & Change in MLS & $\begin{array}{l}\text { Significantly increased in the } \\
\text { placebo group }\end{array}$ \\
\hline & Change in GSRS & $\begin{array}{l}\text { No difference between the two } \\
\text { groups }\end{array}$ \\
\hline & $\begin{array}{l}\text { Change in COX-1 } \\
\text { expression }\end{array}$ & $\begin{array}{l}\text { Significantly higher in the } \\
\text { teprenone group }\end{array}$ \\
\hline & Adverse events & $\begin{array}{l}\text { No significant difference between } \\
\text { the two groups }\end{array}$ \\
\hline \multirow[t]{4}{*}{ Zhao et al. (19) } & Incidence of Gl symptoms & $\begin{array}{l}\text { Significantly higher in the control } \\
\text { group at } 6 \text { and } 12 \text { months but } \\
\text { not at } 3 \text { months }\end{array}$ \\
\hline & Incidence of gastric ulcer & $\begin{array}{l}\text { Significantly higher in the control } \\
\text { group at } 12 \text { months but not at } 3 \\
\text { and } 6 \text { months }\end{array}$ \\
\hline & Incidence of GI bleeding & $\begin{array}{l}\text { No significant difference between } \\
\text { the two groups }\end{array}$ \\
\hline & $\begin{array}{l}\text { Incidence of gastric } \\
\text { erosion }\end{array}$ & $\begin{array}{l}\text { No significant difference between } \\
\text { the two groups }\end{array}$ \\
\hline \multirow{5}{*}{$\begin{array}{l}\text { Gong et al. } \\
\text { (20) }\end{array}$} & Incidence of gastric ulcer & Higher in the control group \\
\hline & Incidence of GI bleeding & $\begin{array}{l}\text { No significant difference between } \\
\text { the two groups }\end{array}$ \\
\hline & Change in MLS & $\begin{array}{l}\text { Significantly increased in the } \\
\text { placebo group }\end{array}$ \\
\hline & Dyspeptic symptom score & $\begin{array}{l}\text { Significantly increased in the } \\
\text { placebo group }\end{array}$ \\
\hline & Adverse events & $\begin{array}{l}\text { No serious adverse events in } \\
\text { either groups }\end{array}$ \\
\hline \multirow[t]{5}{*}{$\begin{array}{l}\text { Takeuchi et al. } \\
\text { (21) }\end{array}$} & Incidence of gastric ulcer & $\begin{array}{l}\text { No significant difference between } \\
\text { the two groups }\end{array}$ \\
\hline & Incidence of GI bleeding & $\begin{array}{l}\text { No significant difference between } \\
\text { the two groups }\end{array}$ \\
\hline & Change in MLS & $\begin{array}{l}\text { Significantly better reduction with } \\
\text { famotidine as compared to } \\
\text { teprenone }\end{array}$ \\
\hline & Incidence of Gl symptoms & $\begin{array}{l}\text { No significant difference between } \\
\text { the two groups }\end{array}$ \\
\hline & Adverse events & $\begin{array}{l}\text { No significant difference between } \\
\text { the two groups }\end{array}$ \\
\hline \multirow[t]{3}{*}{$\begin{array}{l}\text { Xiong et al. } \\
\text { (22) }\end{array}$} & Lewis score & $\begin{array}{l}\text { Significantly higher in the control } \\
\text { group }\end{array}$ \\
\hline & $\begin{array}{l}\text { Severity of small-intestinal } \\
\text { mucosal injuries }\end{array}$ & $\begin{array}{l}\text { Significantly higher in the control } \\
\text { group }\end{array}$ \\
\hline & $\begin{array}{l}\text { Incidence of ulcers and } \\
\text { erosions }\end{array}$ & $\begin{array}{l}\text { Significantly higher in the control } \\
\text { group }\end{array}$ \\
\hline \multirow[t]{2}{*}{ Lu (16) } & Incidence of Gl symptoms & $\begin{array}{l}\text { Significantly higher in the control } \\
\text { group }\end{array}$ \\
\hline & $\begin{array}{l}\text { Fecal occult blood test } \\
\text { score }\end{array}$ & $\begin{array}{l}\text { Significantly higher in the control } \\
\text { group }\end{array}$ \\
\hline
\end{tabular}

(Continued)
TABLE 2 | Continued

\begin{tabular}{lll}
\hline References & Outcome & Result \\
\hline Endoscopy score & $\begin{array}{l}\text { Significantly higher in the control } \\
\text { group } \\
\text { No significant difference between } \\
\text { the two groups }\end{array}$ \\
Wu et al. (17) & Incidence of Gl symptoms & $\begin{array}{l}\text { Significantly higher in the control } \\
\text { group at 3, 6, and } 12 \text { months } \\
\text { Significantly higher in the control } \\
\text { Eroup at 3, 6, and } 12 \text { months }\end{array}$ \\
& Endoscopy score &
\end{tabular}

GSRS, gastrointestinal symptom rating scale; MLS, Modified Lanza score; Gl, gastrointestinal.

our analysis assessing only small intestinal injuries with their results too demonstrating the protective role of teprenone in long-term diclofenac users. However, we were unable to find any more studies assessing the efficacy of teprenone for small intestinal injuries.

An important difference between the seven trials included in our review was the type of NSAID used. Majority studies were conducted on aspirin users while only two studies included patients on other NSAIDs $(20,22)$. Indeed the use of low-dose aspirin for preventing adverse events in patients with cardiovascular and cerebrovascular disease is much more prevalent than the use of NSAIDs for chronic conditions like rheumatic diseases $(1,2)$. Literature suggests that the risk of GI injuries varies with the type of NSAID used $(31,32)$. Owing to the limited number of available studies, it was not possible for this review to separately assess the protective effect of teprenone for different NSAIDs.

Along with NSAID use, infection with $H$. pylori is an important contributor to the etiology of upper GI ulcers (23). Studies have demonstrated that the presence of $H$. pylori can significantly increase the incidence of upper GI mucosal injury $(24,33)$. Amongst the included studies of our review, only two trials $(18,20)$ were conducted on $H$. pylori negative individuals with the majority studies not reporting data on $H$. pylori status of included patients. This is an important limitation while assessing results of our review and future studies should take into account this confounding factor to provide robust results. However, since the included studies were RCTs, it may be plausible to assume that the distribution of $H$. pylori positive patients may have been equal in the study and control groups. Furthermore, the two studies $(18,20)$ pooled for analysis of MLS included only H. pylori negative patients in their trials.

A meta-analysis of MLS scores indicated a non-significant difference between teprenone and control. However, considering the $95 \% \mathrm{CI}$, there was a tendency for better outcomes with teprenone and the non-significant results may be partly attributed to the limited number of studies available for analysis. While ulcers and bleeding are serious complications with longterm NSAID users, their occurrence is relatively rare, and subjective symptoms of dyspepsia, bloating, etc can be a greater cause of concern from the patient's perspective (23). Our results indicated that subjective symptoms are significantly reduced with long-term use of teprenone. However, only three trials were 


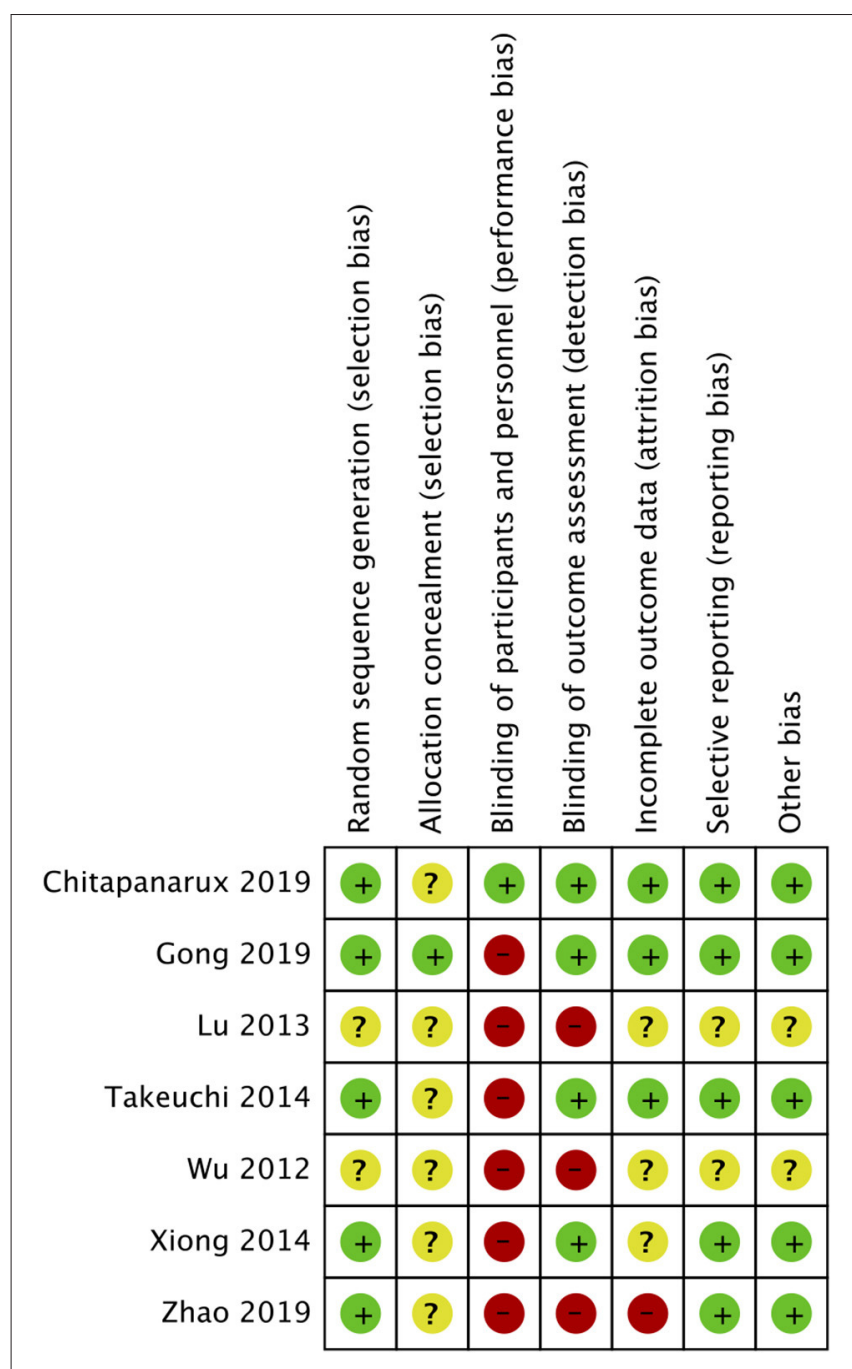

FIGURE 5 | Risk of bias summary.

available for this meta-analysis. It is also important to note that all the three studies were not blinded and subjective symptoms would have been highly influenced due to such bias.

Considering the beneficial effects of teprenone, it would be interesting to compare the efficacy and safety of teprenone with other widely used gastroprotective drugs like PPIs or H2RAs. Our literature search was able to identify only one study comparing teprenone with famotidine with their results demonstrating better outcomes with famotidine. The lower efficacy of teprenone as compared to other drugs has also been demonstrated by studies on patients with dyspeptic symptoms $(34,35)$. The limited number of studies comparing teprenone with other gastroprotective drugs for NSAID-induced GI damage is a major deficiency in current literature. While any gastroprotective agent can be better than placebo, a good measure of the efficacy of teprenone for NSAID-induced GI injuries can only be provided with its comparison with other established drugs. Only future high-quality RCTs with large sample size comparing teprenone with other PPIs or H2Ras can better elucidate the efficacy of teprenone vis-à-vis other drugs. Such studies should also perform a cost-effective analysis to clarify if teprenone is indeed a cheaper alternative to other drugs.

None of the trials comparing teprenone with placebo or famotidine reported any major adverse events with the use of teprenone. None of the patients discontinued teprenone due to an adverse event. Thus, on analysis of the limited number of RCTs, teprenone seems to be safe. However, further long-term studies with larger sample size shall supplement current evidence.

Our study has some limitations. First, several RCTs had a high or unclear risk of bias in multiple domains. The overall certainty of evidence as assessed by GRADE was found to be low for all outcomes. Secondly, the number of included studies in our review was not high and not all RCTs reported similar outcomes for a meta-analysis. Thirdly, our review included studies reporting both gastric as well as small intestinal lesions. As mentioned earlier, $H$. pylori status was not available from all trials. Furthermore, majority studies did not explicitly define GI ulcers. Difference between studies as to what lesion is classified as an ulcer may have introduced variations in the ulcer incidence between trials. Lastly, all trials were conducted only in a limited number of Asian countries, and this limits the generalization of results to the global population. Furthermore, teprenone is currently available only in limited Asian countries with no record of its availability and cost in European or American markets $(36,37)$. This is an important factor which limits the research on this drug in only Asian countries.

Nevertheless, ours is the first systematic review and metaanalysis assessing the efficacy of teprenone for preventing GI injuries in long-term NSAID users. A detailed literature search irrespective of language was carried out to include maximum RCTs. A quantitative and qualitative analysis was performed to present compressive evidence comparing teprenone with control as well as other drugs.

To conclude, low-quality evidence indicates a beneficial role of teprenone in preventing GI ulcers and symptoms in patients receiving long-term NSAIDs. Further high-quality RCTs comparing teprenone with placebo as well as other gastroprotective drugs are needed to strengthen current evidence.

\section{DATA AVAILABILITY STATEMENT}

Publicly available datasets were analyzed in this study. This data can be found here: Databases of PubMed, Embase, BioMed Central, CENTRAL, and Google Scholar.

\section{AUTHOR CONTRIBUTIONS}

CZ conceived, designed the study, and wrote the paper. JW and QX were involved in literature search, data collection, and analyzed the data. QX reviewed and edited the manuscript. All authors read and approved the final manuscript.

\section{SUPPLEMENTARY MATERIAL}

The Supplementary Material for this article can be found online at: https://www.frontiersin.org/articles/10.3389/fmed. 2021.647494/full\#supplementary-material 


\section{REFERENCES}

1. Sutcliffe P, Connock M, Gurung T, Freeman K, Johnson S, Kandala $\mathrm{NB}$, et al. Aspirin for prophylactic use in the primary prevention of cardiovascular disease and cancer: a systematic review and overview of reviews. Health Technol Assess (Rockv). (2013) 17:1-253. doi: 10.3310/ hta17430

2. Crofford LJ. Use of NSAIDs in treating patients with arthritis. Arthritis Res Ther. (2013) 15:S2. doi: 10.1186/ $\operatorname{ar} 4174$

3. Lavie CJ, Howden CW, Scheiman J, Tursi J. Upper gastrointestinal toxicity associated with long-term aspirin therapy: consequences and prevention. Curr Probl Cardiol. (2017) 42:146-64. doi: 10.1016/j.cpcardiol.2017.01.006

4. Raju N, Sobieraj-Teague M, Hirsh J, O'Donnell M, Eikelboom J. Effect of aspirin on mortality in the primary prevention of cardiovascular disease. $\mathrm{Am}$ J Med. (2011) 124:621-9. doi: 10.1016/j.amjmed.2011.01.018

5. Musumba C, Pritchard DM, Pirmohamed M. Review article: cellular and molecular mechanisms of NSAID-induced peptic ulcers. Aliment Pharmacol Ther. (2009) 30:517-31. doi: 10.1111/j.1365-2036.2009. 04086.x

6. Sturkenboom MCJM, Burke TA, Tangelder MJD, Dieleman JP, Walton S, Goldstein JL. Adherence to proton pump inhibitors or H2-receptor antagonists during the use of non-steroidal anti-inflammatory drugs. Aliment Pharmacol Ther. (2003) 18:1137-47. doi: 10.1046/j.1365-2036.2003. 01795.x

7. Yeomans N, Lanas A, Labenz J, Van Zanten SV, Van Rensburg C, Rácz I, et al. Efficacy of esomeprazole ( $20 \mathrm{mg}$ once daily) for reducing the risk of gastroduodenal ulcers associated with continuous use of low-dose aspirin. Am J Gastroenterol. (2008) 103:2465-73. doi: 10.1111/j.1572-0241.2008. 01995.x

8. Kinoshita Y, Ishimura N, Ishihara S. Advantages and disadvantages of long-term proton pump inhibitor use. J Neurogastroenterol Motil. (2018) 24:182-96. doi: 10.5056/jnm18001

9. Charlot M, Grove EL, Hansen PR, Olesen JB, Ahlehoff O, Selmer C, et al. Proton pump inhibitor use and risk of adverse cardiovascular events in aspirin treated patients with first time myocardial infarction: nationwide propensity score matched study. BMJ. (2011) 342:d2690. doi: 10.1136/bmj. $\mathrm{d} 2690$

10. Jamshed S, Bhagavathula AS, Zeeshan Qadar SM, Alauddin U, Shamim S, Hasan S. Cost-effective analysis of proton pump inhibitors in long-term management of gastroesophageal reflux disease: a narrative review. Hosp Pharm. (2020) 55:292-305. doi: 10.1177/0018578719893378

11. Yanaka A, Zhang S, Sato D, Tauchi M, Suzuki H, Shibahara T, et al. Geranylgeranylacetone protects the human gastric mucosa from diclofenacinduced injury via induction of heat shock protein 70. Digestion. (2007) 75:148-55. doi: 10.1159/000106756

12. Iwai T, Ichikawa T, Kida M, Goso Y, Kurihara M, Koizumi W, et al. Protective effect of geranylgeranylacetone against loxoprofen sodiuminduced small intestinal lesions in rats. Eur J Pharmacol. (2011) 652:1215. doi: 10.1016/j.ejphar.2010.11.020

13. Nishida K, Ohta Y, Ishiguro I. Protective and preventive effects of teprenone on gastric mucosal lesions in rats. Eur J Pharmacol. (1998) 354:518. doi: 10.1016/S0014-2999(98)00430-0

14. Moher D, Liberati A, Tetzlaff J, Altman DG, PRISMA Group. Preferred reporting items for systematic reviews and meta-analyses: the PRISMA statement. PLoS Med. (2009) 6:e1000097. doi: 10.1371/journal.pmed. 1000097

15. Higgins J, Thomas J, Chandler J, Cumpston M, Li T, Page M, et al. Cochrane Handbook for Systematic Reviews of Interventions. Version 6. Cochrane (2019). Available online at: https://training.cochrane.org/ handbook/archive/v6 (accessed November 10, 2020).

16. Lu X. Study on protective mechanism of teprenone on aspirin-induced gastric mucosal injury. Chinese J Postgrad Med. (2013) 10:22024.

17. Wu Y, Wen F, Yihong F, Bing L. Protection of gastric mucosa against aspirininduced damage by teprenone. Chinese J Dig. (2012) 32:404-7.

18. Chitapanarux $\mathrm{T}$, Lertprasertsuke $\mathrm{N}$, Kongnak A. Teprenone for the prevention of low-dose aspirin-induced gastric mucosal injury in
Helicobacter pylori-negative patients. Scand J Gastroenterol. (2019) 54:1199-204. doi: 10.1080/00365521.2019.1672781

19. Zhao J, Fan Y, Ye W, Feng W, Hu Y, Cai L, et al. The protective effect of teprenone on aspirin-related gastric mucosal injuries. Gastroenterol Res Pract. (2019) 2019: 6532876. doi: 10.1155/2019/ 6532876

20. Gong Y, Huang X, Chen M, Xiong L. Teprenone improves gastric mucosal injury and dyspeptic symptoms in long-term nonsteroidal anti-inflammatory drug users. J Gastroenterol Hepatol. (2019) 34:1344-50. doi: 10.1111/jgh. 14614

21. Takeuchi T, Ota K, Harada S, Kojima Y, Inoue T, Iwakiri R, et al. Comparison of teprenone and famotidine against gastroduodenal mucosal damage in patients taking low-dose aspirin. J Gastroenterol Hepatol. (2014) 29:115. doi: 10.1111/jgh. 12768

22. Xiong L, Huang X, Li L, Yang X, Liang L, Zhan Z, et al. Geranylgeranylacetone protects against small-intestinal injuries induced by diclofenac in patients with rheumatic diseases: a prospective randomized study. Dig Liver Dis. (2015) 47:280-4. doi: 10.1016/j.dld.2015.01.005

23. Iijima K, Shimosegawa T. Geographic differences in low-dose aspirinassociated gastroduodenal mucosal injury. World J Gastroenterol. (2015) 21:7709-17. doi: 10.3748/wjg.v21.i25.7709

24. Uemura N, Sugano K, Hiraishi H, Shimada K, Goto S, Uchiyama S, et al. Risk factor profiles, drug usage, and prevalence of aspirin-associated gastroduodenal injuries among high-risk cardiovascular Japanese patients: the results from the MAGIC study. J Gastroenterol. (2014) 49:81424. doi: 10.1007/s00535-013-0839-5

25. Yeomans ND, Lanas AI, Talley NJ, Thomson ABR, Daneshjoo R, Eriksson B, et al. Prevalence and incidence of gastroduodenal ulcers during treatment with vascular protective doses of aspirin. Aliment Pharmacol Ther. (2005) 22:795-801. doi: 10.1111/j.1365-2036.2005. 02649.x

26. Hamid S, Yakoob J, Jafri W, Islam S, Abid S, Islam M. Frequency of NSAID induced peptic ulcer disease. J Pak Med Assoc. (2006) 56:218-22.

27. Zhu LL, Xu LC, Chen Y, Zhou Q, Zeng S. Poor awareness of preventing aspirin-induced gastrointestinal injury with combined protective medications. World J Gastroenterol. (2012) 18:316772. doi: $10.3748 /$ wjg.v18.i24.3167

28. Ning JW, Bin LG, Ji F, Xu J, Sharify N. Preventive effects of geranylgeranylacetone on rat ethanolinduced gastritis. World J Gastroenterol. (2012) 18:2262-9. doi: 10.3748/wjg.v18. i18.2262

29. Shirakabe H, Takemoto T, Kobayashi K, Ogoshi K, Kimura K, Nakamura $\mathrm{K}$, et al. Clinical evaluation of teprenone, a mucosal protective agent, in the treatment of patients with gastric ulcers: a nationwide, multicenter clinical study. Clin Ther. (1995) 17:924-35. doi: 10.1016/0149-2918(95) 80070-0

30. Isomura Y, Yamaji Y, Yamada A, Watanabe Y, Suzuki H, Kobayashi Y, et al. Irsogladine improves small-intestinal injuries in regular users of nonsteroidal anti-inflammatory drugs. Gastrointest Endosc. (2014) 80:11825. doi: 10.1016/j.gie.2013.12.030

31. Castellsague J, Riera-Guardia N, Calingaert B, Varas-Lorenzo C, Fourrier-Reglat A, Nicotra F, et al. Individual NSAIDs and upper gastrointestinal complications: a systematic review and metaanalysis of observational studies (the SOS Project). Drug Saf. (2012) 35:1127-46. doi: 10.2165/11633470-000000000-00000

32. Rafaniello C, Ferrajolo C, Sullo MG, Sessa M, Sportiello L, Balzano A, et al. Risk of gastrointestinal complications associated to NSAIDs, low-dose aspirin and their combinations: results of a pharmacovigilance reporting system. Pharmacol Res. (2016) 104:108-14. doi: 10.1016/j.phrs.2015. 12.026

33. Shiotani A, Sakakibara T, Yamanaka Y, Nishi R, Imamura $\mathrm{H}$, Fujita $M$, et al. The preventive factors for aspirin-induced peptic ulcer: aspirin ulcer and corpus atrophy. J Gastroenterol. (2009) 44:717-725. doi: 10.1007/s00535-009-0068-0

34. Hongo M, Harasawa S, Mine T, Sasaki I, Matsueda K, Kusano M, et al. Large-scale randomized clinical study on functional dyspepsia treatment with mosapride or teprenone: Japan Mosapride Mega-Study (JMMS). 
J Gastroenterol Hepatol. (2012) 27:62-8. doi: 10.1111/j.1440-1746.2011. 06949.x

35. Sakurai K, Nagahara A, Inoue K, Akiyama J, Mabe K, Suzuki J, et al. Efficacy of omeprazole, famotidine, mosapride and teprenone in patients with upper gastrointestinal symptoms: an omeprazole-controlled randomized study (JFOCUS). BMC Gastroenterol. (2012) 12: doi: 10.1186/1471-230X-12-42

36. Drugs|FDA. Available online at: https://www.fda.gov/drugs (accessed February 9, 2021).

37. European Medicines Agency. Available online at: https://www.ema.europa.eu/ en (accessed February 9, 2021).
Conflict of Interest: The authors declare that the research was conducted in the absence of any commercial or financial relationships that could be construed as a potential conflict of interest.

Copyright $\odot 2021$ Zhao, Wang and Xiao. This is an open-access article distributed under the terms of the Creative Commons Attribution License (CC BY). The use, distribution or reproduction in other forums is permitted, provided the original author(s) and the copyright owner(s) are credited and that the original publication in this journal is cited, in accordance with accepted academic practice. No use, distribution or reproduction is permitted which does not comply with these terms. 